\title{
NOTAS
}

\section{ENTRE EL DESEO Y LA REALIDAD: APROXIMACIÓN AL INCESTO EN LA COMEDIA ÁUREA*}

En el arsenal del que se nutre el teatro del Siglo de Oro destacan algunos temas que "mueven con fuerza a toda gente", que diría Lope ${ }^{1}$ Aristóteles señalaba que, como tema de la tragedia, los autores debían buscar padecimientos entre "personas unidas por lazos de parentesco" porque éstos despertaban compasión²; precisamente, un aspecto extremo del abanico de conflictos nacidos en el seno de la familia, y que apunta al movere, es el incesto, pues suscita un sentimiento de catarsis equiparable al matricidio o al parricidio. El incesto puede definirse como una relación amorosa -carnal-innatural e ilícita que supone una transgresión de las barreras familiares, con alcances en los órdenes jurídico, social y hasta político; a la vez que permite explorar, en algunas oportunidades, los dominios de las pasiones inaccesibles.

Sin duda, el incesto es un tema de inmensa fuerza dramática y por ello ha despertado la atención de numerosas escuelas de inter-

* Este trabajo se relaciona con el proyecto TC/12 "Patrimonio Teatral clásico español. Textos e instrumentos de investigación" del Programa Consolider-Ingenio 2010, CSD2009-00033; se ha beneficiado de mi participación como colaborador en el proyecto "Red europea: conflictos de autoridad e imágenes del poder. Guerras de propaganda" (segunda fase de "Autoridad y poder en el Siglo de Oro") del Programa Jerónimo de Ayanz del Departamento de Educación del Gobierno de Navarra (Convocatoria 2010-2011) y cuyo investigador principal es Ignacio Arellano. Ha sido redactado durante una estancia de docencia e investigación en la Westfälische Wilhelms-Universität Münster, gracias a la concesión del "Gertraud und Reinhard Horstmann Stipendiumpreis” para el año académico 2011-2012. Una primera versión fue presentada en el Congreso Internacional "Palabra y poder: silencios y secretos en el teatro del Siglo de Oro" (Viena, 14-15 de mayo de 2012), con el título, "Secretos peligrosos: del incesto en la comedia áurea", gracias a la invitación de Wolfram Aichinger.

${ }^{1}$ LOPE DE VEGA, Arte nuevo de hacer comedias, ed. E. Rodríguez Cuadros, Castalia, Madrid, 2011, v. 328.

2 Aristóteles, Poética, ed. y trad. A. Villar Lecumberri, Alianza, Madrid, 2004, XIV, 1453b. Para las ediciones de las obras aludidas, véase corpus en el Apéndice. 
pretación. Su doble atributo de sagrado (o impuro) y vedado nace de su condición de tabú, protegido por ciertas normas cuyo incumplimiento acarrea un castigo. La prohibición del incesto es una constante universal, cuya causa se ha explicado de diversas maneras, mas su función se resume en mantener la unidad familiar y formar la personalidad del hombre futuro ${ }^{3}$. El incesto se entrecruza con el adulterio y la endogamia; ya desde la Antigüedad se rechazaban las relaciones entre parientes cercanos: Platón condenaba la unión sexual entre miembros de la familia nuclear y lo juzgaba como una acción impía y vergonzosa ${ }^{4}$, en Roma se prohibió por ius divinum y se contemplaba como una conducta criminal, etc. En la Biblia se veda el incesto ${ }^{5}$ y la Iglesia añade el parentesco espiritual, pero hasta De incestis coniuctionibus del Silense no se distingue entre el incesto marital y la fornicación incestuosa entre parientes. Se registran numerosos ejemplos en los anales de la historia (la familia Borgia, el supuesto enamoramiento del príncipe Carlos por Isabel de Valois, el interés de don Juan de Austria por María Teresa...) y, al margen de diversos mitos (Biblis, Cánace, Fedra, Mirra y Filomena), en las páginas de la literatura se contemplan hechos incestuosos en drama, poesía y prosa ${ }^{6}$. Súmese a ello, por último, el trasfondo biográfico reiterado para el conflicto paterno-filial en la dramaturgia de Calderón ${ }^{7}$.

${ }^{3}$ E. Frenzel, Diccionario de motivos literarios de la literatura universal, trad. M. Albella Martin, Gredos, Madrid, 1980, pp. 180-181. Véase B. T. BoeHrer, Monarchy and incest in Renaissance England. Literature, culture, kinship and kingship, University of Pennsylvania, Philadelphia, 1992; R.A. MCCABE, Incest, drama and nature's law: 15501700, Cambridge University, Cambridge, 1993; E. Archibald, Incest and the Medieval imagination, Oxford University, Oxford, 2001; E. LACARra Lanz, "Incesto marital en el derecho y en la literatura europea medieval", Clío y Crimen, 7 (2010), 16-40 [núm. especial: Pecado-crimen y penitencia-castigo en la Edad Media a través de la literatura y el arte, ed. I. Bazán; disponible en: http://www.durango-udala.net/portalDurango/ RecursosWeb/ DOCUMENTOS/1/4_3437_1.pdf, consultado el 21 de diciembre de 2011; M. MitTerauer, "Die «Sitten der Magier». Zur Inzestproblematik in historischen Gesellschaften", en Historische Verwandtschaftsforschung, en prensa.

4 Platón, Leyes, ed. y trad. J. M. Pabón y M. Fernández Galiano, Alianza, Madrid, 2002, VIII, 838c.

${ }^{5}$ En el Levítico (18-20). Los enlaces incestuosos documentados en las Escrituras se justifican, según san Agustín, debido a que era un sistema preciso para poblar el mundo recién creado, pero teniendo en cuenta la caridad y "cuando ello fue posible por la abundancia" fue un deber "tomar por esposas a las que no eran hermanas, y no habiendo necesidad de esa práctica, se consideraba algo nefasto el conservarla" (san Agustín de Hipona, La Ciudad de Dios, eds. S. Santamarta del Río, M. Fuertes Lanero, V. Capánaga y T. Calvo Madrid, BAC, Madrid, 2009, 15, 16).

6 Tampoco Zeus fue ajeno al incesto: yació con su madre Rea, se casó con su hermana Hera, etc. La unión con Juno aparece en Los tres mayores imperios de Pablo Polope, que Bances ve en 1687 (F.A. De Bances Candamo, Teatro de los teatros de los pasados y presentes siglos, ed. D.W. Moir, Tamesis, London, 1970).

7 Por mucho que quiera O. Rank (Das Inzest-Motiv in Dichtung und Sage. Grundzüge einer Psychologie des dichterischen Schaffens, Deuticke, Leipzig, 1912, pp. 557-561) 


\section{MODALIDADES}

Como fuere, de esta encrucijada entre teoría y praxis el incesto salta a la ficción dramática. En la comedia hay cuatro categorías a partir de dos constantes principales y sus posibilidades combinatorias: el incesto puede consumarse o no; y puede darse entre padres e hijos (vertical) o en el nivel fraterno (horizontal o lateral), paradigma más frecuente en el teatro áureo ${ }^{8}$. Surge así un cuarteto en que cada punto puede ejemplificarse con títulos áureos bien conocidos:

1. Incesto consumado entre padres e hijos: los actores involucrados en esta relación suelen ser madre e hijo, no padre e hija, como en El castigo sin venganza de Lope, si bien Casandra es madrastra y no madre natural de Federico ${ }^{9}$.

2. Incesto cumplido entre hermanos: La venganza de Tamary Los cabellos de Absalón, con la violación de Tamar a manos de Amón.

3. Incesto no consumado en el nivel vertical: la desenfrenada pasión de la reina por su hijo Ninias en La gran Semíramis de Virués.

4. Incesto no culminado en el nivel horizontal: se trata del grupo más nutrido y seguramente el mejor exponente sea La devoción de la cruz de Calderón.

Más allá de esta tipología didáctica, debe diferenciarse entre la acción consciente y aquella hecha sin intención, pues frente al rigor

con base en erróneos datos biográficos. Véase D.W. Cruickshank, Calderón de la Barca. Su carrera secular, trad. J. L. Gil Aristu, Gredos, Madrid, 2011, pp. 99-101. No hallo ninguna demostración a estas inferencias.

8 E. ARChibald escribe: "In classical stories mother-son incest seems to be fairly rare, and is always presented as the most shocking relationship, but when it is deliberate on the part of the mother it is regarded as particularly monstruous", mientras que "Father-daughter incest is almost always initiated by the father... and often takes the form of rape" (op. cit., p. 102); a la vez, el incesto entre hermanos parece proliferar ya en relatos de la temprana modernidad. E. LACARra LANZ (art. cit., pp. 31-32), señala que hay dos paradigmas de matrimonios incestuosos más frecuentes en la literatura europea: entre hijos y madres, en ocasiones seguidos de parricidio; y entre padres e hijas, generalmente no consumados porque éstas se mutilan y/o se alejan para evitarlo. Véase J.M. Ford, Patriarchy and incest from Shakespeare to Joyce, University of Florida, Gainesville, 1998, pp. 1-35, 146-169.

9 E. Frenzel señala que la relación madre-hijo es la menos representada, contra lo que decía Freud, porque "se opone a la fundamental concepción poética de una pareja amorosa", mientras que en el amor entre madrastra e hijastro "el incesto no atenta contra el parentesco de sangre, sino sólo de ley" y hay una mayor afinidad de edad (op. cit., p. 181). E. LACARRA LANZ (art. cit., p. 18) advierte que es habitual que el padre no logre satisfacer sus deseos con su hija, pues el incesto se esquiva o Dios perdona al pecador arrepentido. 
punitivo que reclama la primera, no hay pecado alguno en la ignorancia, toda vez que el atractivo procede en numerosas ocasiones de lazos familiares ocultos - por abandono y/o separación en la infancia- y no es necesario recurrir a supuestos deseos inconscientes, según se verá. Tampoco estaría de más atender al estatuto social de los personajes, ya que en algunos casos se relaciona con la esfera del poder y el conflicto personal se entrelaza con la sociedad; $y$, por último, a los incestos derivados de la inventiva de los poetas (comedias "de fantasía”) en oposición a aquellos tomados de fuentes bíblicas, históricas o mitológicas (Antíoco y Seleuco, de Moreto, La púrpura de la rosa, de Calderón, Progne y Filomena, en versiones de Guillén de Castro y Rojas Zorrilla...) que orientan su tratamiento dramático, sin olvidar los cambios anejos al género y sus convenciones.

\section{DE LA AMENAZA A LA TRAGEDIA: LA CONSUMACIÓN DEL INGESTO}

Se inicia el recorrido con el mito de Edipo, tan común y fatalmente mal interpretado. En gran parte se debe a Freud, cuya lectura de Edipo rey de Sófocles abrió la veda a la detección de un complejo con pies de barro: el deseo inconsciente de mantener una relación sexual con el progenitor del sexo opuesto (incesto) y eliminar al del mismo sexo (parricidio $)^{10}$. El gran error de esta lectura simplificada y de alcance limitado -pero innegablemente sugerente- es prescindir de la ironía trágica y del concepto de ignorancia invencible que domina la acción de la leyenda.

El enfrentamiento paterno-filial es inexistente: no hay oposición efectiva porque ninguno conoce la relación que les une. Edipo, de hecho, huye de Corinto para evitar acabar con quienes cree sus padres. Luego la irónica secuencia de sucesos hace que el hombre al que vence en un cruce de caminos sea Layo, pero hay que tener en cuenta que en la versión original probablemente Edipo no conocía todavía el oráculo fatídico, ignorancia todavía mayor que explica que no albergue ningún remordimiento ni sospecha ${ }^{11}$. Pero nunca hay

10 Así es la variante positiva. La negativa consiste en desear al progenitor del mismo sexo y rechazar al de sexo opuesto. Freud expone, matiza y revisa sus ideas en Sobre las teorías sexuales infantiles, 1908; Sobre un tipo particular de la elección de objeto en el hombre (Contribuciones a la psicología del amor, I), 1910; Tótem y tabú, 1913; Algunas consecuencias psíquicas de la diferencia anatómica entre los sexos, 1925. Nótese que Freud no se refiere a la tragedia sofoclea, sino al horizonte psíquico del público. Véase la clásica respuesta de J.P. Vernant, "Edipo sin complejo", en Mito y tragedia en la Grecia antigua, de J.P. Vernant y P. Vidal-Naquet, trad. M. Armiño, Taurus, Madrid, 1987, t. 1, pp. 79-100; y la excelente síntesis de C. García Gual, Enigmático Edipo: mito y tragedia, F.C.E., Madrid, 2012.

11 Y disminuya con ello su dudosa culpa. Véase C. García Gual, op. cit., pp. 84-85, 90-92. Si hubiese conciencia en el enfrentamiento se trataría de un reflejo 
intencionalidad en el relato: "Ninguno de aquellos hechos fue voluntario”, se lee en Edipo en Colono ${ }^{12}$. Con ello juega la versión de Séneca, donde al saber la verdad el personaje recuerda que Pólibo y Mérope viven, y acusa a Creonte de conspirar contra él ${ }^{13}$. De más está decir que el matrimonio político entre Edipo y Yocasta no se asienta en un deseo transgresor, de modo que el héroe es víctima de una ignorancia invencible que conduce a la desgracia.

Estos apuntes valen para los ecos edípicos de diversos dramas del Siglo de Oro. El ejemplo paradigmático es La devoción de la cruz de Calderón, comedia religiosa de juventud donde el incesto es una amenaza que recorre la acción dramática ${ }^{14}$. Eusebio y Julia se ven separados al nacer debido a que Curcio asesina -o eso parece- a su madre, Rosmira, por unas imaginadas sospechas de infidelidad; esta escena constituye un ejemplo de uxoricidio singularmente violento y patético por la inocencia de la esposa y la actuación del matador. Con el tiempo, los hermanos que se habían separado se conocen y se sienten atraídos, pero la diferencia social y la muerte de Lisardo a manos de Eusebio abre un abismo entre los amantes. Éste, enajenado, decide luego asaltar el sagrado y gozar a su amada. El conflicto se agrava por el estado religioso de Julia, que implica una cierta dosis de oposición a la divinidad (reflejado en las imágenes de Ícaro y Faetón, vv. 14061407), pero no creo que critique la moral eclesiástica y conventual

del mito de Uranos, como estudia F. Ruiz Ramón para La vida es sueño ("El «mito de Uranos» en La vida es sueño", en Teatro del Siglo de Oro. Homenaje a Alberto Navarro González, Reichenberger, Kassel, 1990, pp. 547-562). Otras historias cercanas que representan un efectivo enfrentamiento paterno-filial son Zeus contra Cronos o Prometeo frente a Zeus, etc., pero su ingrediente político es ajeno a La devoción de la cruz.

12 Sófocles, Edipo rey. Edipo en Colono. Antígona, ed. y trad. J. Schere, Colihue, Buenos Aires, 2008, vv. 522-523.

13 SÉneca, Edipo, en Tragedias II, ed. y trad. J. Luque Moreno, Gredos, Madrid, 1980, vv. 659-707.

${ }^{14}$ La primera versión de la comedia (La cruz en la sepultura) se fecha en 16221623, publicada en partes y sueltas desde 1628-1629. En su forma final aparece en la Primera parte (1636). Véase A.J. SÁEz, "De Edipo y sus variantes: en torno a las fuentes de La devoción de la cruz, de Calderón”, en Actas del IX Congreso de la Asociación Internacional del Siglo de Oro (Poitiers, 11-15 de julio de 2011), ed. A. Bégue, IberoamericanaVervuert, Madrid-Frankfurt/M. (en prensa), y "Violencia y poder en La devoción de la cruz", en La violencia en Calderón. Actas del XVI Coloquio Anglogermano sobre Calderón (Utrecht y Ámsterdam, 18-22 de julio de 2011), eds. M. Tietz y G. Arnscheidt (en prensa). El incesto puede ser un paso más en una cadena de pecados. Así aparece el deseo de don Gil por Leonor, habiendo ya gozado a su hermana Lisarda; dice el demonio: "Y pues que tienes amor / a Leonor, aunque es incesto, / haré que la goces presto" (A. Mira de Amescua, El esclavo del demonio, ed. J.M. Villanueva Fernández, en Teatro completo, coord. A. de la Granja, Diputación de Granada-Universidad, Granada, 2004, t. 4, vv. 1472-1474). Referencia que, por cierto, no se suele aclarar: el incesto en este texto radica en que don Gil ya ha tenido contacto carnal con una de las hermanas. 
como alguno imagina ${ }^{15}$. La tensión crece a marchas forzadas hasta que la visión del símbolo de la cruz en el pecho de Julia -idéntica a la suya- evita in extremis que se consume la terrible unión y provoca la progresiva anagnórisis.

No puede apuntarse a una relación incestuosa porque el parentesco no es conocido ni se culmina, pues en el momento en que Eusebio contempla la marca en el pecho de Julia desiste de su pasión y huye (vv. 1606-1619). El peligro nace de la incorrecta interpretación de su atracción mutua, que no viene de la pasión amorosa, sino de la fuerza de la sangre: el parentesco que les une y que se descubre por pasos. Mientras la realidad familiar permanece en la penumbra, la buscada unión entre Eusebio y Julia funciona en el esquema amoroso de galanteo y desnivel social, propio de tantas comedias, que hace que la acción avance (léase el duelo con Lisardo y sus efectos). En este sentido, los crímenes y la amenaza de incesto constituyen un eslabón más en una cadena de responsabilidad compartida desde la acción inicial de Curcio ${ }^{16}$.

Se trata de una interesante variedad, ya que la tragedia humana se entrecruza y finalmente se ve superada por la acción redentora de la cruz en una pieza de intensa dimensión religiosa. La amenaza de incesto funciona en la dinámica entre el pecado y la gracia como motivo dramático que se revela progresivamente y realza el poder de la cruz, símbolo del orden sobrenatural que conjura el peligro y encamina a la conversión ${ }^{17}$.

15 Así A. Rodríguez López-VÁzQuez, "La significación política del incesto en el teatro de Calderón", en Les mentalités dans la Péninsule Ibérique et en Amérique Latine aux xvi et xviie siècles. Histoire et problématique. Actes du XIII éme Congrès de la "Société des Hispanistes Français de l'Enseignement Supérieur" (Tours, 1977), dir. A. Redondo, Université de Tours, Tours, 1978, p. 109. También debe matizarse el desafío a la autoridad real que implica la rebeldía contra el padre.

${ }^{16}$ Para la responsabilidad difusa, véase A.A. PARKer, "Aproximación al drama español del Siglo de Oro", en Calderón y la crítica, eds. M. Durán y R. Echeverría, Gredos, Madrid, 1976, t. 1, pp. 346-352.

17 R. Giles estudia las señales cruciformes de Eusebio y Julia en la tradición de la anagnórisis hagiográfica, en concreto con la historia de santa Inés de Roma (Leyenda áurea y otras versiones) y el relato de una joven de Antioquía que cuenta el obispo Ambrosio de Milán ("Parentescos carnales y espirituales: la anagnórisis hagiográfica y el peligro de incesto en La devoción de la cruz", en Calderón: del manuscrito a la escena, eds. F.A. de Armas y L. García Lorenzo, Iberoamericana-Vervuert, Madrid-Frankfurt/M., 2011, pp. 261-280). Acierta al señalar que si "las escenas de reconocimiento y reintegración en el teatro y el romance griego se habían centrado características en lazos de sangre, el descubrimiento de un parentesco está basado en una unidad interior de términos familiares, y no destinada a producir pathos, sino más bien una afirmación de la verdad eterna (gaudium)" (pp. 272-273). En cambio, se equivoca al incidir en la importancia de los augurios astrológicos en la comedia y al afirmar que la marca en el pecho que posee Julia desde su nacimiento es prueba de la inocencia de su madre Rosmira (p. 263), y parece exagerado decir que estos signos "funcionan como símbolos del castigo divino y de los desastres divinos que 
Parece poco dudoso que Calderón desarrollara algunos aspectos de La devoción de la cruz para redactar Las tres justicias en una ${ }^{18}$. El joven don Lope se lanza al crimen por un conflicto de amores y el constante enfrentamiento con su padre, Lope de Urrea, que contrasta con el cariño para con su madre ${ }^{19}$. Aunque es perdonado por la autoridad y se reconcilia con su progenitor, la disputa amorosa por Violante desata otra vez su violencia. Ya encerrado se descubre la verdad: es hijo de don Mendo -justicia mayor del reino-, y Laura, hermana de Blanca -quien hizo pasar al niño por suyo tras la muerte de la madre. Esto explica la tensa relación paterno-filial, el inmediato aprecio surgido entre Lope y Mendo ${ }^{20}$, y la mutua atracción de Lope y Violante, que, medio hermanos, confunden la llamada de la sangre con el amor.

La tentativa de incesto goza de menor desarrollo y se vincula con el conflicto de identidad y el ejercicio del poder regio. Delgado Morales opina que se trata de una "metáfora... de determinadas formas de corrupción política y social”, porque la atracción de los hermanos es "efecto o síntoma del desorden moral existente en el entorno familiar", nunca su "causa primera o principal" ${ }^{21}$. En efecto, la existencia del joven Lope se ve condicionada por ciertas acciones que contravienen la ley natural: la boda desigual y forzada de Lope con Blanca, y el abandono de Laura por Mendo, que dan pie a una serie de engaños que provocan el peligro de incesto, la desorientación moral del galán y el desorden social que sólo es parcialmente restaurado al final.

Nuevamente un padre (Mendo) hostiga a su hijo (Lope) para que sea castigado sin conocer la naturaleza de sus lazos. Y al igual que el enfermizo ejercicio del poder de Curcio repercute en la tragedia familiar, Lope purga la culpa propia y ajena, según expone Mendo en aparte: "¡Ay, hijo!, castigo has sido / dilatado de mi culpa / hasta aquí" (vv. 3008-3010). El rey no es misericordioso, sino que castiga

forman parte del plan salvífico de Dios", pues la cruz no es un signo dual, "a la vez maléfico y protector" (p. 268).

18 Tal como dice D.W. Cruickshank, op. cit., p. 247.

19 No ha de leerse necesariamente como una pasión incestuosa, según hacen A. RODRíGUEz LóPEZ-VÁzQUEz, "Lo sagrado frente a lo político: el incesto y los atributos de la justicia”, $C u H, 1980$, núm. 357, p. 662; H.W. Sullivan y E. Ragland-Sullivan, "Las tres justicias en una of Calderón and the question of Christian catharsis", en Critical perspectives on Calderón de la Barca, eds. F.A. de Armas, D.M. Gitlitz y J.A. Madrigal, Society of Spanish and Spanish-American Studies, Lincoln, 1981, pp. 132-134.

${ }^{20} \mathrm{Su}$ encuentro es inverso al de Edipo y Layo, porque el bandolero (Lope) perdona a quien es su padre (A. RodRíGuez López-VÁzQUEz, "Lo sagrado frente a lo político...”, pp. 659 y 665$)$.

${ }^{21}$ M. Delgado Morales, "Incesto, ley natural y orden social en Las tres justicias en una", en Calderón: innovación y legado. Actas selectas del IX Congreso de la Asociación Internacional de Teatro Español y Novohispano de los Siglos de Oro (Pamplona, 27 al 29 de marzo de 2000), dirs. I. Arellano y G. Vega García-Luengos, Peter Lang, New York, 2001, p. 111. 
públicamente al criminal; sin embargo, la administración de justicia es algo irregular: informado de todos los hechos, el rey opta por silenciar los atenuantes de Lope, con lo que encubre los errores y difiere el merecido castigo de sus padres naturales y putativos, foco de origen de la culpabilidad en la comedia ${ }^{22}$.

Frente a estos casos de anagnórisis, la historia de Semíramis ofrece otras soluciones al incesto, un motivo tomado de algunas versiones de la historia (Justino, Dante, Boccaccio) y del que prescinde Calderón en La hija del aire. La gran Semíramis de Virués, buen representante del teatro del horror del siglo XVI, dramatiza una medida consciente por parte del amenazado: disgustado por las desvergüenzas de su madre y su propuesta, Ninias la atraviesa con su espada, sumando el matricidio al incesto. La corte del demonio de Vélez de Guevara muestra ese amor correspondido en un ambiente donde reinan las relaciones incestuosas y poligámicas por consejo de Lucero (el demonio) y en una vuelta de tuerca algo forzada llega la conversión gracias a la intervención de Jonás.

\section{ÉTICA PRIVADA Y PÚBLICA}

Por este camino destacan algunas piezas en las que el motivo de origen particular se articula con la esfera pública; es decir, tiene repercusiones en la sociedad, porque los personajes poseen una dimensión política que debe primar. Según la clásica metáfora de los dos cuerpos del rey han de tener en cuenta su doble estatuto humano y político para dominar sus pasiones en beneficio del orden social y del bien común. Así, la resistencia al apetito incestuoso es un mérito más del príncipe perfecto en El hijo de los leones y El primero Benavides, de Lope, Virtudes vencen señales, de Vélez de Guevara y Los hermanos amantes y piedad por fuerza, de Fernando de Zárate ${ }^{23}$. Por el contrario, la caída en el pecado refleja el desgobierno de las figuras del poder a la par que activa los mecanismos trágicos que conducen a la violación del tabú y al lastimoso final.

En El castigo sin venganza, el matrimonio de conveniencia del duque con Casandra se complica en una relación triangular con el bastardo conde Federico. Al desagrado inicial que siente éste ante el peligro de no heredar el Estado, sucede la atracción mutua despertada en el primer encuentro con su madrastra, lo que ante

22 M. Delgado Morales, art. cit., pp. 117-119. El monarca no castiga la burla de Mendo ni el engaño de Blanca, pero su carta (vv. 3016-3023) contiene referencias a sus delitos, expiados en la muerte de Lope.

23 F. Antonucci, "Algunas notas sobre la autoría de El nieto de su padre", Criticón, 51 (1991), p. 19. El nieto de su padre de Guillén de Castro muestra el resultado de la lascivia del tirano Boemundo, que le lleva al incesto con su hija, desconocedores de sus vínculos de sangre. 
la mayor correspondencia entre ambos y la incapacidad del duque por alejarse de las correrías licenciosas, abre la puerta a un territorio vedado. Así, este prohibido amor permite a Casandra vengarse de su ingrato marido consumando el incesto (legal, no de sangre) entre madrastra y alnado durante la ausencia del duque, una transgresión no representada en escena sino decorosamente acaecida entre los actos segundo y tercero.

La reforma interna del duque a su regreso es tardía y ante el delito debe actuar cual garante de la justicia, pero cuidando que no se publique su infamia y pueda conservar su honra:

$$
\begin{aligned}
& \text { Seré padre y no marido, } \\
& \text { dando la justicia santa } \\
& \text { a un pecado sin vergüenza } \\
& \text { un castigo sin venganza }{ }^{24} \text {. }
\end{aligned}
$$

Justifica la punición de su hijo por haber quebrantado el mandamiento divino de honrar al padre en una acción que puede leerse como un castigo a sus propios excesos mujeriegos, una suerte de justicia poética que devuelve la misma moneda al pecador (vv. 2508-2521). La traición privada y familiar posee una dimensión pública que agrava el crimen, pues la víctima es la máxima autoridad política, y de ello se vale el duque; orquesta que la ofensa pasional y personal se convierta en una traición, una rebelión motivada por celos y ambición: hace que su hijo acabe con un conspirador desmayado que es Casandra, y éste luego es ejecutado por matar a su madrastra debido a que esperaba un heredero legítimo, pretensión a la que ella había renunciado explícitamente.

Pese a la resistencia que los personajes oponen a la fuerza de sus pasiones (Casandra y Federico) y al intento de conciliar el amor y el deber (el duque), se cumple el incesto que ha de ser castigado. Esto constituye el centro y clímax del drama diseñado por Lope, quien sigue la tradición desde la historia original de Bandello ${ }^{25}$ en el énfasis que otorga a una acción mucho más grave que el simple adulterio: pues si la unión carnal entre hermanos se podía permitir en algunas sociedades -no en la española-, el encuentro materno-filial es inadmisible por su carácter todavía más anormal y transgresor ${ }^{26}$. Al fin, el resultado de las fallas y las trágicas acciones de los tres protagonistas

24 El castigo sin venganza, ed. A. García Reidy, Crítica, Barcelona, 2009, vv. 28462849.

25 Matteo Bandello, Novelle, 1554, 44.

26 M. Alvar, "Reelaboración y creación en El castigo sin venganza", en "El castigo sin venganza” y el teatro de Lope de Vega, ed. R. Doménech, Cátedra, Madrid, 1987, pp. 211, 218-219. Mantiene que se plantea la relación familiar madre-hijo en lugar de la real de madrastra-entenado, cuestión dudosa en tanto sería un atentado muy grave contra el decoro. 
dejan Ferrara al borde del abismo, convertido en un ducado del que los personajes desean salir, presos del horror.

En Los cabellos de Absalón se presenta la violación de Tamar a manos de Amón, rendido a su pasión y al mal consejo de Jonadab, quien persuade a su señor alegando que sólo comparten la ascendencia paterna, o sea, que no son más que medio hermanos ${ }^{27}$. Se suma aquí el agravante de la violencia sexual, más grave en el relato bíblico que el incesto ${ }^{28}$. Una vez saciado su apetito, rechaza a su hermana y el rey comienza a hacer gala de su debilidad: esta violación incestuosa -falta el consentimiento presente en El castigo sin venganza- reclama un castigo que David no administra ante la sumisión del culpable y la conciencia de sus propias culpas (episodio de Urías y Betsabé). La hamartia del monarca es su excesiva tendencia al perdón para con sus hijos, cuyo descontrol no ataja al subordinar sus deberes políticos en favor de sus afectos. Esta injusta decisión despierta la ira del ambicioso Absalón, quien decide tomarse la justicia por su mano y sacar dos beneficios de una muerte: vengar a su hermana (también de madre) y eliminar a su mayor rival al trono, para lo que no duda en faltar a la palabra que da a su padre de salvaguardar la vida de Amón. Es la chispa que incendia el frágil equilibrio social de la comedia: se desata la guerra civil y el resultado es la desgracia familiar y política. Otra vez el incesto se proyecta sobre la situación social y política en un ambiente de descontrol de las pasiones y desgobierno de los poderosos que no puede culminar sino en catástrofe.

$\mathrm{Al}$ hilo, recuérdese que el fracaso de la instancia paterna es un rasgo propio de la visión trágica calderoniana y una opción al reto de crear una tragedia en la España católica del siglo XviI era la inversión del final edípico $^{29}$. O una relectura cristiana: Celos son bien y ventura de Godínez muestra a Albano, expósito de un incesto paterno-filial, que mata al rey y

27 Nótese que Amón no acepta la solución que le sugiere Tamar: pedir su mano a David (Los cabellos de Absalón, ed. E. Rodríguez Cuadros, Espasa Calpe, Madrid, 1989, vv. 963-965), pues la ley hebraica permitía estas uniones.

28 Así lo destaca R. Fine ("Relaciones peligrosas. En torno al incesto y la violación en tres novelas ejemplares: La española inglesa, La fuerza de la sangre y La ilustre fregona", en Recreaciones bíblicas cervantinas, Iberoamericana-Vervuert, MadridFrankfurt/M., en prensa), cuyo manejo agradezco a la autora. No puedo comentar su compleja relación con La venganza de Tamar: baste recordar que la segunda jornada de Calderón es casi idéntica a la tercera tirsiana, cuestión muy debatida por la crítica; de hecho, se le ha atribuido la autoría del acto que reutiliza.

29 M. Vitse, Éléments pour une théorie du théâtre espagnol du XVII siècle, $2^{\mathrm{a}} \mathrm{ed}$., Presses Universitaires du Mirail, Toulouse, 1990; M.R. GreER, "Perspectivas trágicas sobre la historia: la casa de David en el siglo Xvı", en Hacia la tragedia áurea. Lecturas para un nuevo milenio, eds. F.A. de Armas, L. García Lorenzo y E. García Santo-Tomás, Iberoamericana-Vervuert, Madrid-Frankfurt/M., 2008, p. 128: "en un número significante de tragedias españolas, es el padre quien destruye o bien al hijo, o a la esposa que por el amor y el sacramento matrimonial se ha hecho parte de su ser". 
la princesa de Escandinavia, con quien iba a casarse, para acabar sus días como santo, perdonado por Dios cual ejecutor de su castigo.

Otro caso de descontrol se verifica en El caballero bobo de Guillén de Castro: el príncipe Lotario no renuncia al amor que siente por su hermana y decide valerse del parecido con el prometido de su amada, a quien mata y cuyo lugar ocupa para casarse con ella. No importa que el parentesco sea simulado (Estrella se finge Aurora), sino el error de un poderoso vencido por el apetito. En este sentido, Enrique VIII (La cisma de Ingalaterra de Calderón) y Trebacio (El triunfo de la humildad y soberbia abatida de Lope) se escudan tras supuestos escrúpulos sobre que sus esposas (Catalina y Felisarda) han sido antes mujeres de sus hermanos para separarse de ellas y poder saciar sus nuevos deseos.

\section{TrazAS DE COMEDIA}

A pesar de prestarse al tratamiento trágico, el incesto puede aparecer en textos cómicos. Se enmarca entonces en la dinámica de simulación de la identidad y enredos amorosos, y puede culminar en matrimonio gracias a la llegada de la dispensa oportuna, que autoriza la unión entre parientes de cierto grado de consanguinidad, especialmente primos, para evitar la pena de excomunión.

A partir de ahí se juega con las distintas opciones del fingimiento de identidades. Es intencionado en El semejante a sí mismo de Ruiz de Alarcón: don Juan prueba el amor de su prima doña Ana, a quien corteja bajo máscara de don Diego en un trueque de papeles que acaba, previa dispensación, en feliz casamiento. Por el contrario, don Rodrigo es confundido con Otón en El castigo del penseque de Tirso y Clavela siente amor hacia su falso hermano, pasión que pronto sospecha pasa del sentimiento de fraternidad y trata de alejar de sí; por su parte, don Fernando en El parecido de Moreto es tomado por un caballero indiano al que daban por muerto y él finge haber perdido la memoria a fin de poder galantear a su supuesta hermana. El incesto también puede creerse una amenaza real entre parientes en la ficción: Marcela teme ser amada por su hermano en La entretenida de Cervantes, pero sólo es un malentendido generado por sinonimia; Amor es naturaleza de Vélez de Guevara presenta una enajenación temporal del duque César, quien al ser forzado a renunciar a su amada trata de casarse con su hermana hasta la restauración final ${ }^{30}$. Sin embargo, en estos textos el motivo del incesto aparece apenas dibujado.

30 Para R. GiRARD (La violencia y lo sagrado, trad. J. Jordá, Anagrama, Barcelona, 1983 , p. 83) el incesto es una forma de violencia extrema y contagiosa que elimina las diferencias en la familia, un efecto con el que se juega en la comedia. 
Mayor desarrollo alcanza en ¿De cuándo acá nos vino? de Lope. El alférez Leonardo viaja a Madrid para gestionar un premio a sus servicios; una vez allí falsifica una carta del capitán Fajardo y se finge su hijo para lograr la ayuda de su hermana, doña Bárbara. De paso puede acercarse a la hija de ésta, doña Ángela, de quien se ha enamorado. Por si fuera poco, a Bárbara le atrae su sobrino y se convierte en rival de Ángela. En teoría, la simulada relación familiar impide la unión con cualquiera de las dos damas, pero una dispensa podría permitir el matrimonio con ambas. Así, Bárbara quiere casar a su hija con otro para tener el camino libre y miente para forzarla: dice que Leonardo es su hijo, con lo que su amor resulta imposible. Pero la maraña se descubre pronto y, cuando los amantes resuelven engañar a Bárbara para casarse, llega Fajardo y pone orden en el mar de confusiones: tras su enojo inicial perdona los embustes de Leonardo, lo acepta por hijo y dispone su matrimonio con Ángela, que a Bárbara no le queda más que aceptar. El vínculo de consanguinidad lleva de la mano el peligro de incesto y ambos funcionan en la comedia como ardides para impedir o facilitar las uniones amorosas de los personajes.

El parentesco fingido sirve principalmente al ingenioso Leonardo, pero Bárbara añade otra pieza al rompecabezas para forzar la renuncia de su hija. Es, pues, una traza cómica similar a la simulación de piedad en Marta la piadosa de Tirso, que permite al galán acercarse a la dama antes de su entrada en el convento. Recuérdese, asimismo, que el parentesco es un amparo frecuente para las relaciones amorosas: Periandro y Auristela en Los trabajos de Persiles y Sigismunda se fingen hermanos hasta llegar a Roma, Elena y Montúfar ocultan su vínculo prostibulario en La hija de Celestina de Salas Barbadillo, etc. ${ }^{31}$.

Algo similar ocurre en La discreta enamorada de Lope: el viejo Bernardo, padre de su amado Lucindo, solicita la mano de Fenisa, y ella simula corresponder su pretensión y traza que Lucindo corteje a Belisa, su propia madre; de este modo gana tiempo para lograr su meta, quedando al final emparejados Fenisa con Lucindo y Bernardo con Belisa. El amor fingido, con los límites y transgresiones derivados (Lucindo cortejando a Fenisa, su futura madre, por ejemplo), esquiva las dificultades que surgen al amor de los personajes principales. Por todo ello, el tratamiento del motivo del incesto en ¿De cuándo acá nos vino?, La discreta enamorada y las otras comedias cómicas carece de toda dimensión trágica y se enmarca en el alarde de ingenio que

31 Recuérdese aquí de la mano de C. Guillén, la distinción entre "lo que Cervantes en el Persiles llama «hermanazgo fingido», o sea, el que se finjan hermanos los enamorados que se conocieron siendo ya mayores, para ocultarse o ampararse de los peligros que les rodean, o para poner a prueba su amor o su castidad; y la situación de dos niños que se crían juntos como hermanos" (El primer Siglo de Oro: estudios sobre géneros y modelos, Crítica, Barcelona, 1998, p. 197, n. 48). 
caracteriza a las figuras que pueblan el universo cómico ${ }^{32}$. Ya no es una terrible amenaza, por lo que pueden considerarse incestos no sólo sin consumar, sino inocentes o ingenuos.

El género pone coto al incesto, que no puede materializarse en una pieza cómica y lúdica. Tiene cabida en el argumento, pero no se explotan sus posibilidades trágicas. Un botón: la verdadera identidad de Arcombroto, que crece creyendo ser hijo de Hianisbe, pero es fruto del amor secreto y fugaz de su hermana con el rey de Sicilia, no se revela más que para impedir que se case con su hermana Argenis; una situación muy similar a Las tres justicias en una -que acaba en desgracia- se salda con felices bodas en Argenis y Poliarco.

De modo similar, recuerdo que en otros terrenos también cómicos, como el teatro breve y la comedia burlesca, se da un paso más y el incesto se convierte en blanco de parodia y chiste, al igual que tantos otros motivos en su mundo invertido y carnavalesco.

Una última advertencia metodológica: hay que cuidarse contra las desviaciones interpretativas de algún sector de la crítica que aprecia relaciones incestuosas donde no las hay -más allá de confusiones entre parentescos encubiertos y deseos conscientes. No sé si es debido a una mala lectura o fruto de pulsiones ocultas, que diría alguno. Dejo de lado la inventada presencia del tema del incesto en La dama duende, según una lectura trágica que tergiversa la comicidad de esta pieza de capa y espada, y que se ampara en el lamento de doña Ángela sobre su escasa libertad $^{33}$. En La gran sultana de Cervantes, el padre de Catalina abraza a su hija nada más verla, momento en que el sultán le avisa:

32 Al margen, no parece que ¿De cuándo acá...? contenga una serie de reproches a la institución de la dispensa, especialmente a su coste y demora (como pretende E. Vivó de UndabarRena, “¿De cuándo acá nos vino?: Lope de Vega y el tabú del incesto”, Revista de Derecho UNED, 2010, núm. 6, 485-534), pues son elementos que contribuyen al desarrollo de la intriga y al desenlace. La cantidad de mil escudos sirven a Leonardo para paliar su apurada situación económica y la demora de la dispensa -cuyos trámites en realidad nunca se inician-posibilitan que no se efectúe su matrimonio con doña Bárbara. El género también limita el alcance de posibles críticas: así, el lugar para disertar sobre ello es un tratado, como hace Saavedra Fajardo en Introducciones a la política y razón de estado del rey católico don Fernando. De modo similar, en El vaquero de Moraña la protagonista finge por un momento que va a casarse con el padre para evitar los amores del hijo.

33 Véase la respuesta de I. Arellano, El escenario cósmico. Estudios sobre la comedia de Calderón, Iberoamericana-Vervuert, Madrid-Frankfurt/M., 2006, pp. 189-191. Esta perspectiva algo maliciosa conlleva ver una atracción entre hermanos (M.R. Álvarez Sellers, Análisis y evolución de la tragedia española en el Siglo de Oro: la tragedia amorosa, Reichenberger, Kassel, 1997, t. 3, pp. 733-734, n. 23) en un parlamento de don Diego en No hay cosa como callar: "No me trates ahora como hermano; / trátame como amante, pues es llano / que lo soy, ya que no de tu belleza, / de tu virtud" (ed. K. F. Delmondes, Universidad de Navarra, Pamplona, 2009 [trabajo de investigación tutelado], vv. 1247-1250). Sobre un posible incesto en La vida es sueño, véase F.A. DE Armas, The return of Astrea. An astral-imperial myth in Calderón, University of Kentucky, Kentucky, 1986, pp. 108-115. 
Cristiano amigo, eso no, que algo toca en desvergüenza. Tanteadla desde fuera y no lleguéis a tocalla ${ }^{34}$.

Jurado Santos ve una alusión al incesto "en el estallido de celos del sultán y en la prohibición de un posible contacto entre el padre y Catalina"35. Ahora bien, no existe ningún deseo sexual entre ambos, sino alegría -y algo de sorpresa en la dama- por su reencuentro y la realidad de su parentesco no es conocida por el líder turco hasta que el propio personaje se presenta, por lo que su advertencia se dirige a un sastre cautivo (disfraz adoptado por el padre) que toma las medidas de un vestido para Catalina, un gesto -eso sí- tópicamente envidiado por la cercanía que entraña con el cuerpo femenino.

\section{ENTRE EL DESEO Y LA VOZ DE LA SANGRE}

Claramente prima en el teatro el motivo del incesto fraterno, habitualmente reducido a amenaza. Es frecuente que derive de un temprano abandono o separación de los hermanos, que provoca la confusión al menos inicial de las fronteras entre el deseo y el amor familiar; un paradigma repetido en el tema del salvaje ${ }^{36}$. En la dramaturgia calderoniana aparece en numerosas piezas, pero en general sólo se refiere como un hecho pasado (El purgatorio de san Patricio) o no llega a cumplirse, como el constante rechazo de Floripes al amor de Fierabrás en La puente de Mantible. De hecho, este argumento se ha esgrimido para dudar de la autoría de la primera jornada de Los cabellos de Absalón en que Amón fuerza a Tamar, hermana sólo por vía paterna ${ }^{37}$. Ahora,

${ }^{34}$ La gran sultana, ed. L. Gómez Canseco, Biblioteca Nueva, Madrid, 2010, vv. $1811-1814$.

35 A. Jurado Santos, Tolerancia y ambigüedad en "La gran sultana" de Cervantes, Reichenberger, Kassel, 1997, p. 23.

${ }^{36}$ Por tanto, O. Rank (op. cit., pp. 557-561) yerra en su percepción del motivo del incesto fraterno en una serie de comedias (El triunfo de la humildad y soberbia abatida, El vaquero de Moraña, y Las almenas de Toro de Lope). F. Antonucar (op. cit.) señala diversos ejemplos de esta confusión inicial: El nacimiento de Ursón y Valentín y El conde Alarcos de Lope; Leoncio y Montano de Diego y José de Figueroa y Córdoba. En este sentido vale la tesis de C. LÉvi-STrauss (Las estructuras elementales del parentesco, trad. M.T. Cevasco, $2^{\mathrm{a}}$ ed., Paidós, Barcelona-Buenos Aires, 1988, pp. 17, 41-59 [original: Les structures élémentaires de la parenté, PUF, Paris, 1949]), para quien la prohibición del incesto se sitúa en el paso de la naturaleza a la cultura en tanto regla de carácter universal y restrictivo que opera también en el seno de fenómenos ajenos a la sociedad, si bien se explica preferentemente por causas sociológicas.

37 Véase Los cabellos de Absalón, ed. cit., p. 16, n. 6. O. RANk (op. cit.) aduce el rechazo de Calderón a describir claramente una violación incestuosa. 
en muchos de estos dramas (Argenis y Poliarco, Hado y divisa de Leonido y Marfisa, La devoción de la cruz, Las tres justicias en una) el parentesco es desconocido y su revelación impide que se consume una "pasión equivocada” (p. 134), en definición de Marfisa.

El mucho menor número de deseos incestuosos entre padres e hijos se debe, según creo, a que se concibe como una transgresión más grave contra la jerarquía de autoridad familiar y atenta contra el respeto debido a la figura paterna, o un caso de maldad extrema como en El Anticristo ${ }^{38}$. El parentesco espiritual no parece atraer la mirada de los dramaturgos y nótese, además, que los pocos casos de incesto culminados tienen lugar, no entre familiares directos, sino de segundo grado en adelante, como hermanos de un único progenitor (Amón y Tamar, de origen bíblico) o parientes por vía legal (la madrastra Casandra y su alnado Federico). Por ello, queda fuera de duda que el teatro privilegia con mucho las relaciones incestuosas entre parientes frente al incesto marital, quizás en un ejercicio de autocensura a fin de evitar toda ofensa al sacramento del matrimonio. Incluso si se llega hasta ahí: sólo tengo noticia de El marido de su madre de Matos Fragoso, donde no se conoce el parentesco, los esposos no yacen juntos y la verdad disuelve el enlace, un cambio frente a la consumación involuntaria de la leyenda de Gregorio Magno.

En cualquier caso, no hay la actitud ambivalente de deseo y horror ante el incesto que explica Freud ${ }^{39}$, pues el amor llega hasta las puertas de la anagnórisis: "no hay deseo en sangre propia", escribe Lope ${ }^{40}$. La diferencia es muy clara en el Siglo de Oro: el parentesco es afinidad que "la sangre le da" y los amantes se unen por una atracción que "en el alma está”, según se aclara en Amor es naturaleza ${ }^{41}$. No hay rebelión

38 Así ocurre en la mayoría de culturas y en la Edad Media (E. Archibald, op. cit., p. 229). No es preciso, pues, mantener que la hija sustituye a la figura de la madre, tan escasa en el teatro de Calderón (A. Rodríguez López-VÁzQuez, "La significación política...”, p. 108). Sobre esto, véase M. CAAmaño Rojo, “Teatro y sociedad: sobre la madre en la comedia calderoniana”, en Calderón y el pensamiento ideológico y cultural de su época. XIV Coloquio Anglogermano sobre Calderón (Heidelberg, 24-28 de julio de 2005), eds. M. Tietz y G. Arnscheidt, Franz Steiner, Stuttgart, 2008, pp. 129-144, y "Pseudoausencia y pseudopresencia de la madre en Calderón", en La madre en el teatro clásico español. Personaje y referencia, coord. L. García Lorenzo, Fundamentos, Madrid, 2012, pp. 119-146; D.W. Cruickshank, op. cit., pp. 74-75. O. Rank (op. cit., pp. 559 y 561), se equivoca al ver atracciones incestuosas entre padres e hijos en $L a$ niña de plata de Lope y El amor constante y El desengaño dichoso de Guillén de Castro.

39 S. Freud, Tótem y tabú. Algunas concordancias en la vida anímica de los salvajes y de los neuróticos, ed. y trad. L. López Ballesteros y de Torres, $4^{\mathrm{a}}$ ed., Alianza, Madrid, 1970, pp. 7-101.

40 El primero Benavides, ed. S. Iriso Ariz, en Comedias de Lope de Vega. Parte II.2, coord. S. Iriso Ariz, Milenio, 1998, v. 2454.

41 Amor es naturaleza, Alonso del Riego, Valladolid, s.a., f. 6v (ejemplar de la Biblioteca Histórica de Madrid: Tea 1-2-3; suelta atribuida a J. Pérez de Montalbán: http://bib.cervantesvirtual.com/FichaObra.html?Ref=40132; consultado el 12 de 
consciente del individuo contra la moral social que prohíbe el incesto, un rasgo propio del Romanticismo ${ }^{42}$ : al sufrimiento por una pasión imposible sigue la aceptación, y la única reacción dispar la toma el rey Sancho, que ordena matar a una bella dama al saber que es su hermana para que nadie la goce (Las almenas de Toro). Por eso, en juego con el título de un poemario de Cernuda se resume el conflicto en el debate entre el deseo y la realidad, en el paso de uno a otro.

\section{SOBRe LAS TABlAS: EL LÍMITE DEL DECORO Y OTRAS GUESTIONES}

La tipología anterior revela la mayor frecuencia de incestos no consumados en el teatro. Es un recurso dramático ya contemplado por la Poética aristotélica: estar "a punto de perpetrar, por ignorancia, un hecho irreparable", que se evita por el reconocimiento previo (XIV, 1453b). Junto a ello, la interpretación de la comedia áurea ha de considerar algunas fronteras, y el concepto de decoro constituye un parámetro esencial que explica que la espada de Damocles del incesto se mantenga pendiente y no llegue a caer mortalmente.

Este concepto abarca dos variantes en el siglo XVII ${ }^{43}$ : el decoro propiamente dramático, consistente en la adecuación de la conducta y el lenguaje de los personajes a las convenciones de su papel (jerarquía dramática, nivel social...); y el moral, que veda la representación de determinados motivos sobre las tablas y presenta notables variaciones según los polemistas, ya que depende en última instancia del gusto del público. Determina el territorio de lo aceptable en la ficción desde el punto de vista moral: así, los adulterios, las rebeliones, los uxoricidios, etc., no deben tener lugar sobre el escenario, sino entre bastidores y luego ya puede mostrarse el trágico resultado, por unas fronteras que varían en función del marco genérico y sus convenciones, como se ha visto.

Con el decoro moral se huye de la escenificación de los aspectos vulgares de la realidad, es decir: muerte, sexualidad y violencia. Quede claro que la comedia áurea aceptaba los lances luctuosos y

enero de 2012). En Para vencer a amor, querer vencerle, Margarita expresa a César la dificultad de pasar de primo a esposo: "Desde que nací, os miré / como a mi primo; y no es fácil / miraros hoy como a esposo, / sin dar tiempo a que el carácter / impreso de tantos días / se borre, para que halle / una imagen en lugar / adonde dejé otra imagen. / Demás, de que como os miro / como pariente, me hace / el miraros como a dueño / una novedad tan grande, / un desagrado, un horror, / un miedo, un temor cobarde, / un embarazo, un respeto, / un..." (en Sexta parte de comedias, ed. J. M. Viña Liste, Fundación José Antonio de Castro, Madrid, 2010, p. 1224).

42 Véase R.P. SEbold, "El incesto, el suicidio y el primer Romanticismo español”, $H R, 41$ (1973), 669-692.

43 I. Arellano, Historia del teatro español del siglo XVII, Cátedra, Madrid, 1995, p. 125 . 
violentos, pero su representación guardaba ciertos límites y tendían a situarse en el pasado dramático o entre bastidores. Por otra parte, es obvio que la censura no permitía que el incesto o cualquier otra acción sexual explícita se diese en la escena.

De ahí se explica la limitación que posee en la mayoría de las ocasiones el alcance del incesto y justifica que de amenaza en potencia no evolucione a desgracia en acto, o sea un hecho atroz acontecido en el pasado. La fianza satisfecha atribuida a Lope es un buen exponente. Leonido es un monstruo de violencia desatada cuya primera aparición en escena da la nota característica de sus actos: pretende gozar de su hermana Marcela atraído únicamente por lo infame de la acción. Dice:

$$
\begin{aligned}
& \text { no la quiero gozar } \\
& \text { porque la tengo afición: } \\
& \text { que ni su amor me maltrata, } \\
& \text { ni su talle me aficiona, } \\
& \text { ni me agrada su persona, } \\
& \text { ni su donaire me mata, } \\
& \text { ni su gracia me contenta, } \\
& \text { ni de su lengua yo gusto; } \\
& \text { sí solo porque es mi gusto } \\
& \text { dar a mi sangre esta afrenta }{ }^{44} \text {. }
\end{aligned}
$$

Aunque fracasa, se acumulan sus crímenes: golpea y humilla a su padre, reniega del cristianismo... y confiesa en su curriculum de vicios que también trató de forzar a su madre, a quien arrebató la vida al encontrar resistencia (wv. 691-694); vuelve a tratar de gozar de su hermana, espoleado por la afrenta que supone el acto, y ciega a su padre para que no pueda ser testigo de un deseo que tampoco logra saciar. Nada frena su violencia hasta que la aparición de Cristo provoca su conversión y muere crucificado en pago por sus culpas.

Justamente la presencia de este motivo es un argumento esgrimido contra la licitud del teatro por ser una academia de vicios. En su Discurso teológico sobre los teatros y comedias de este siglo (1689), el padre Ignacio Camargo critica con dureza que todas las comedias del momento suelen terminar "en una comunicación deshonesta, en una correspondencia escandalosa, en un incesto, en un adulterio" ${ }^{45}$. A esta andanada responde Bances Candamo en su Teatro de los teatros: defien-

44 La fianza satisfecha, atribuida a Lope, ed. W.M. Whitby y R. R. Anderson, Cambridge University, Cambridge, 1971, vv. 35-44.

45 I. Camargo, Discurso teológico sobre los teatros y comedias de este siglo, en Preceptiva dramática española del Renacimiento y el Barroco, eds. F. Sánchez Escribano y A. Porqueras Mayo, 2a ed., Gredos, Madrid, 1972, p. 327. 
de que "las comedias modernas no son pecaminosas por sus argumentos" (p. 36), ni en los dramas historiales (de fuente bíblica o profana) ni en las comedias amatorias. Frente a acusaciones anteriores, Bances atiende al cierre de los textos para juzgar la honestidad del teatro y señala acertadamente que ninguna pieza acaba en adulterio o incesto ${ }^{46}$. Estos delitos accionan los mecanismos dramáticos y culminan en arrepentimiento o castigo ejemplar para restaurar -mejor o peor- el orden social. Así, se pueden aprender virtudes: "todo el discurso de la comedia puede ser escuela de los buenos casados y el fin terror de los malos" (p. 34). Y especialmente elogia el arte de Calderón, "quien dio decoro a las tablas y puso norma a la comedia española” (p. 28).

Bances detiene su pluma en una cuestión que late en la esencia misma del teatro: la verdad teatral, la mímesis que trata de sumergir al espectador en una sensación de realidad, malentendida por Navarro en sus Cartas apologéticas (1684). No importa que el incesto culminado sea fingido en El infierno de amor de Galhegos: como ficción el teatro busca que el hombre, dentro y fuera del drama, viva "la misma crisis que si el incesto existiese realmente" y como si fuese vivido por él mismo. Porque a decir de Rozas, tanto el incesto ficticio como los finales convencionales "eran una salida, verdaderamente sincera muchas veces, para ese binomio de fe y moral, para esa disociación de poeta y hombre. Y lo problemático, al quererse disfrazar, se hacía aún más problemático, más teatral" 47 .

FINAL

El motivo del incesto se erige, pues, en exponente de acción transgresora y violenta cuya terrible amenaza pocas veces llega a efecto. Los dramaturgos disponen de todo el catálogo posible de acciones lamentables en la familia que expone Aristóteles ${ }^{48}$ y su tratamiento con base en los parámetros de culminación y conciencia del acto, con efectos que van desde la gravedad de la intención al atenuante de culpa si hay ignorancia. Conviene acentuar algunos puntos clave:

1) Su consumación y representación sobre las tablas se restringe por interés dramático y decoro moral: en general, el alcance del incesto se limita a una confusión de los personajes entre la afinidad fami-

46 Escribe: "Yo no he visto que ningún galán case con su hermana ni con su madre. Sólo en la comedia San Gregorio [El marido de su madre de Matos Fragoso] se ve por un acaso y una ignorancia, pero ni aquellos personajes se supone casar con mala fe, ni allí se aprueba. Sólo se expone por ejemplo, y si esto se vedara también quitaran de contarlo en su historia” (p. 34).

47 J.M. Rozas, "La licitud del teatro y otras cuestiones literarias en Bances Candamo, escritor límite”, Segismundo, 1 (1965), núm. 2, pp. 260, 261.

48 Poética, XIV, 1453b-1454a. 
liar con la llamada del amor, que cede paso al tratamiento dramático de un tema escabroso, y si se quiere, algo al fondo se acompaña del sufrimiento causado por una pasión prohibida. El conflicto se sitúa, pues, entre el deseo amoroso y la voz de la sangre, sin necesidad de acudir a teorías sobre el inconsciente.

2) Si el peligro se concentra en el seno fraterno, probablemente se debe a que se percibía como una transgresión menor que por línea vertical, y permitía que el camino llegase a buen puerto.

3) El género establece algunas coordenadas: en los dramas puede haber conciencia o ignorancia de la relación familiar y la amenaza puede realizarse o conjurarse en el último suspiro, mientras las comedias cómicas se valen del fingimiento y nunca llega la sangre al río. Habitante tanto de universos trágicos como cómicos, prueba una vez más -ya lo veía Bances- la inexistencia de temas exclusivos de una u otra dimensión y aboga por centrar la mirada en el tratamiento que recibe a tenor de las convenciones respectivas.

4) En todo caso y especialmente en piezas serias, la presencia del incesto produce un efecto catártico que favorece la función moralizante que pretende apartar de los caminos del vicio y la perdición mediante el movere y la presentación de un caso ex contrario, un valor reiterado en los debates sobre la licitud del teatro.

En suma, parece lógico pensar de antemano que el incesto es un tema tabú en el teatro del Siglo de Oro (en la literatura no representada hay otra problemática). Pero lo es y no lo es: sí por los límites donde actúa y se desarrolla, dentro de los parámetros señalados, y no porque su recurrencia en el repertorio dramático prueba su fuerza de atracción para el auditorio. 


\section{APÉNDICE}

\section{CORPUS}

Calderón De La Barca, Pedro, Argenis y Poliarco. Ed. A. Vara López. Iberoamericana-Vervuert, Madrid-Frankfurt/M. (en prensa).

$\longrightarrow$, El purgatorio de san Patricio. Ed. J.M. Ruano de la Haza. Liverpool University, Liverpool, 1988.

- En la vida todo es verdad y todo mentira. Ed. D. W. Cruickshank. Tamesis, London, 1971.

- Hado y divisa de Leonido y Marfisa, en Verdadera quinta parte de comedias. Ed. J.M. Ruano de la Haza. Fundación José Antonio de Castro, Madrid, 2010, pp. 85-231. 2001.

, La cisma de Ingalaterra. Ed. J.M. Escudero. Reichenberger, Kassel, Barcelona, 2006.

— Madrid-Frankfurt/M. (en prensa).

—, La puente de Mantible. Eds. F. Rodríguez-Gallego y A. J. Sáez. Iberoamericana-Vervuert, Madrid-Frankfurt/M. (en prensa).

- , Las tres justicias en una. Ed. I. Benabu. Reichenberger, Kassel, 1991.

Castro, G. De, El caballero bobo, en Obras completas. Ed. J. Oleza. Fundación José Antonio de Castro, Madrid, 1997, t. 1, pp. 117-213.

— El nieto de su padre, en Obras de don Guillén de Castro y Bellvís. Ed. E. Juliá Martínez. Tipografía de la Revista de Archivos, Madrid, 1927, t. 3, pp. 200-235.

, Progne y Filomena, en Obras de don Guillén de Castro y Bellvís, t. 1, pp. 121-164.

Cervantes, M. De, La entretenida, en Obra completa. Eds. F. Sevilla Arroyo y A. Rey Hazas. Centro de Estudios Cervantinos, Alcalá de Henares, 1995, t. 3, pp. 667-772.

Galhegos, M. DE, El infierno de amor, en Manuel de Galhegos. Um poeta entre a Monarquia e Monarquia Dual e a Restauraçao, de H. Martins. Cisial, Anadia, 1964, pp. 97-189.

Godínez, F., Celos son bien y ventura, en Parte treinta y cinco de comedias nuevas escritas por los mejores ingenios de España. Lucas Antonio de Bedmar, Madrid, 1671, pp. 236-274. Ejemplar BNE: R/22688 [Disponible en: http:/ / descargas.cervantesvirtual.com/servlet/ SirveObras/12937738665964872976402/038559.pdf?incr=1; consultado el 18 de enero de 2012].

Matos Fragoso, J. De, El marido de su madre, en Primera parte de comedias de don Juan de Matos Fragoso. Julián de Paredes, Madrid, 1658, ff. 108r-128v.

Moreto, A. DE, A buen padre mejor hijo o Antíoco y Seleuco. Ed. H. Urzáiz Tortajada, en Comedias de Agustín Moreto. Primera parte de comedias. Dir. M. L. Lobato. Reichenberger, Kassel, 2011, t. 3, pp. 411-590.

— , El parecido. Ed. L. Castillo Roselló (texto disponible en: http:/ /www. moretianos.com/comedias.html\#; consultado el 10 de enero de 2012). 
Rojas Zorrilla, F. De, Progne y Filomena. Ed. J.J. Pastor Comín, en Obras completas. T. 3: Primera parte de comedias. Dir. M.L. Lobato. Universidad de Castilla-La Mancha, Cuenca, 2011, pp. 425-576.

Ruiz de Alarcón, J., El Anticristo, en Piezas maestras del teatro teológico español. Ed. N. González Ruiz. BAC, Madrid, 1946, t. 1, pp. 418-466.

— El semejante a sí mismo, en Primera parte de las obras completas. Ed. A.V. Ebersole. Adelphi University, New York, 1966, pp. 107-138.

Tirso de Molina (Fray Gabriel Téllez), El castigo del penseque, en Obras completas de Tirso de Molina. T. 3: Doce comedias nuevas. Eds. P. Palomo e I. Prieto. Fundación José Antonio de Castro, Madrid, 1997, pp. 659-760.

VEGA, LoPe DE, ¿¿De cuándo acá nos vino? Ed. D. Gavela García. Reichenberger, Kassel, 2008.

—, El hijo de los leones, en Obras de Lope de Vega. Obras dramáticas 12. Ed. E. Cotarelo y Mori. RAE, Madrid, 1930, pp. 269-298.

, El triunfo de la humildad y soberbia vencida, en Obras de Lope de Vega. Obras dramáticas 10. Ed. F. Ruiz Morcuende, pp. 73-112.

- El vaquero de Moraña. Ed. S. Eiroa, en Comedias de Lope de Vega. Parte 8.3. Coord. R. Ramos. Milenio, Lleida, 2009, pp. 1253-1386. 738.

, La carbonera, en Obras de Lope de Vega. Obras dramáticas 10, pp. 706-

, La discreta enamorada, en Comedias. Eds. J. Gómez y P. Cuenca. Fundación José Antonio de Castro, Madrid, 1998, t. 15, pp. 875-976.

- , Las almenas de Toro. Ed. T.E. Case. University of North Carolina, Chapel Hill, 1971.

Vélez de Guevara, L., La corte del demonio. Eds. W. R. Manson y C. G. Peale; introd. de M. Yaquelín Caba. Juan de la Cuesta, Newark, 2006.

- Virtudes vencen señales. Eds. W.R. Manson y C. G. Peale, introd. de J.M. Ruano de la Haza. Juan de la Cuesta, Newark, 2010.

Virués, C. De, La gran Semíramis. Elisa Dido. Ed. A. Hermenegildo. Cátedra, Madrid, 2003.

ZÁrAte, F. DE (ANTONio EnríQuez Gómez), Los hermanos amantes y piedad por fuerza, en Parte cuarenta de comedias nuevas de diversos autores. Juan de Paredes, Madrid, 1675, ff. 139v-166v. 